\title{
ELEVENTH GRADERS' ACTUAL USE OF ENGLISH LISTENING LEARNING STRATEGIES AT DUONG VAN DUONG HIGH SCHOOL
}

\author{
Duong My Tham ${ }^{1, *}$, Tran Thi Hoang Trang' ${ }^{2}$, Tran Quoc Thao \\ 1. Nong Lam University - Ho Chi Minh City, \\ Linh Trung, Thu Duc, Ho Chi Minh City, Vietnam \\ 2. Duong Van Duong High School, \\ 39 street no. 6, Phu Xuan, Nha Be, Ho Chi Minh City, Vietnam \\ 3. Ho Chi Minh City University of Technology, \\ 475A Dien Bien Phu, Ward 25, Binh Thanh, Ho Chi Minh City, Vietnam
}

Received 7 November 2018

Revised 24 January 2019; Accepted 31 January 2019

\begin{abstract}
It is undeniable that listening comprehension is a fundamental skill in the process of acquiring a language and plays a crucial part in communication although it is not an easy task which requires both background knowledge and linguistic understanding. Therefore, language learners are supposed to employ listening learning strategies to facilitate the process of decoding oral input. This study aimed at examining if the eleventh graders at Duong Van Duong high school used English listening learning strategies and then exploring the frequency of the students' use of these strategies. The present study is a mixed-methods research project in which both qualitative and quantitative data were collected through closed-ended questionnaire and semi-structured interview with the participation of 425 respondents and 20 interviewees. The results of the study indicated that a vast number of the participants employed listening learning strategies at different levels of frequency which were classified into three main groups, namely high use (e.g. cognitive and affective strategies), moderate use (e.g. metacognitive and social strategies) and low use (e.g. compensation and memory strategies).
\end{abstract}

Keywords: EFL listening comprehension, eleventh graders, listening learning strategies, Vietnamese EFL context

\section{Introduction}

It is universally acknowledged that listening is one of the four basic skills of language acquisition (Ellis, 1997; Harmer, 2007). However, it may cause confusion and misunderstanding to EFL/ESL learners if they cannot comprehend what people say in terms of sound, intonation and stress,

\footnotetext{
" Corresponding author. Tel.: 84-979814242

Email: tham.duongmy@hcmuaf.edu.vn
}

colloquial vocabulary, and each may use a different accent, etc. (Ur, 1984, Wilson, 2008). In reality, listening skill has not been considerably emphasized in English language education at most Vietnamese high schools; as a consequence, teaching and learning this receptive skill is not as effective as expected (Nguyen, 2013).

Moreover, Vietnamese students in high school are not equipped with appropriate strategies to develop their listening 
comprehension independently (Do, 2007; Nguyen \& Tran, 2015). That is why there is a need to provide the students with tactics facilitating their listening skill as Brown (2006, p.6) pinpoints, "strategies are clearly a way to ease the burden of listening and should be taught."

According to Vandergrift (2007), listening learning strategies refer to "strategies that listeners consciously or unconsciously use in order to understand, analyze, and interpret a text" (p.101). It has been further stated that effective use of appropriate listening strategies facilitates understanding listening texts especially in the early stages of learning a language. Evidently, good language learners typically employ their cognitive and metacognitive strategies, whereas less proficient listeners tend to work at a wordlevel and try to translate what they hear into their first language without relating it to their personal knowledge (Berne, 2004).

Meanwhile, Wenden and Rubin (1987) describe language learning strategies as "any sets of operations, steps, plans, routines used by the learner to facilitate the obtaining, storage, retrieval, and use of information" (p.19). In the same line, learning strategies are defined as "special thoughts or behaviors that individuals use to help them comprehend, learn, or retain new information" (O'Malley \& Chamot, 1990, p.1). This means that when language learners encounter language learning tasks such as reading or listening, they can use different strategies to complete the tasks.

In terms of categories, listening skill consists of an array of strategies which are divided into distinguished categories. O'Malley and Chamot (1990) affirm that in the process of listening comprehension, there are three different types of strategies, that is, (1) metacognitive strategies, (2) cognitive strategies, and (3) socio-affective strategies. In particular, metacognitive strategies involve planning, monitoring and evaluating comprehension, whilst cognitive strategies are used to manipulate information, and socioaffective strategies are related to the ways that learners decide to interact with others.

More specifically, Oxford classifies listening learning strategies into two main groups: direct and indirect strategies, based upon the extent to which they relate to language. Remarkably, these two strategies are not separate or contradictory, but closely interdependent. Direct strategies, as the name implies, are directly related to the intellectual processing of language such as memorization of vocabulary, or form recognition. They are used to deal with new information and work with language in different tasks and situations. On the other hand, indirect strategies have no direct relevance to language as direct strategies. It simply solves problems about language learning like planning and making schedules for learning and enhancing listeners' positive emotions.

In general, it has been suggested that in order to overcome listening comprehension problems, learners need to develop listening strategies. Based on the significance of listening strategies in developing individuals' listening proficiency, the objectives of this study were (1) to examine whether or not the $11^{\text {th }}$ graders at a high school in Ho Chi Minh city, Vietnam used listening strategies in their listening comprehension and (2) to investigate the frequency of their use of listening learning strategies. In order to achieve these objectives, the following research questions were formulated:

1. Do the $11^{\text {th }}$ graders use listening strategies to facilitate their listening comprehension? 
2. To what extent do they employ these listening learning strategies?

\section{Methodology}

\subsection{Participants}

The participants of the present study consisted of 425 students who were in grade 11 in a high school located in Ho Chi Minh city, Vietnam. Overall, the participants were generally at pre-intermediate level, as determined by entrance and class examinations.

\subsection{Instruments}

The instruments employed in this study included closed-ended questionnaire and semi-structured interview. First, the questionnaire was designed in a multiplechoice format with five points ranging from 1 to $5(1=$ never, $2=$ rarely, $3=$ occasionally, $4=$ frequently, $5=$ always). Based on calculated interval coefficient for four intervals in five points $(5-1=4)$, intervals with the range of 0.80 (4/5) were arranged. Hence, the following criteria in the Likert type scale were used to interpret the data: Never (1.00 - 1.80); rarely (1.81 - 2.60); occasionally (2.61 - 3.40); frequently (3.41 - 4.20); always (4.21 - 5.00). The questionnaire was divided into two parts with the total number of 20 items: personal information ( 2 items) and the students' actual utilization of listening learning strategies (17 items). To avoid the language barrier, the questionnaire was designed in Vietnamese. Furthermore, the reliability of a questionnaire was tested through Cronbach's Alpha with the coefficient of .75 which proved that the questionnaire was acceptably reliable.

Second, semi-structured interview was used to gain an insight into the actual use of listening learning strategies by the eleventh graders. Only 20 interviewees were selected for the separate interviews which were carried out in Vietnamese to ensure the accuracy of the interviewed data. The interviewees were labeled from the first (SI1) to the twentieth (SI20).

\subsection{Data collection and analysis}

Concerning data collection procedure, one of the researchers who was teaching at this high school came to the participants' classes to introduce the purpose and significance of the study. Then, the questionnaires were delivered to the students in class and an instruction how to fill the questionnaires was clarified and explained carefully to them. The students were asked to complete the questionnaires and return them in the following week. After collecting the questionnaires, the researcher and her coresearcher conducted 20 interview sessions. Each interview which was tape-recorded for later transcription lasted almost 20 minutes.

Regarding data analysis, to analyze the data obtained from the questionnaire, it was necessary to employ SPSS 20.0 in which descriptive statistics including Mean (M), Standard Deviation (SD), Frequencies (F), and Percentages (P) were processed, whereas content analysis was employed to deal with qualitative data.

\section{Results and discussion}

Concerning the research question which investigated if listening learning strategies were employed by the high school students, it can be seen in Figure 1 that 368 out of 425 (86.5\%) respondents showed their preference for using these strategies while dealing with listening texts. Surprisingly, a small number of the students surveyed (9.9\%) did not use any listening strategies, and very few participants $(3.6 \%)$ were undecided about the use of listening strategies during the process of their listening comprehension. It can be inferred that most of the students realized that they benefited from these listening learning strategies. 


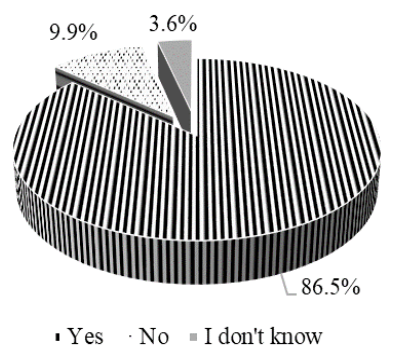

Figure 1. Students' opinions on whether or not they used listening learning strategies

With the aim to explore to what extent listening learning strategies were used by the eleventh graders, both quantitative and qualitative data were analyzed and discussed below. Based on the average mean scores of the strategy groups, overall, these strategies employed with varying frequencies were categorized into three main groups: high use (e.g. cognitive and affective strategies), moderate use (e.g. metacognitive and social strategies) and low use (e.g. compensation and memory strategies).

\subsection{Memory strategies}

Table 1 demonstrated the frequency rate of using memory strategies among the eleventh graders. As can be seen in Table 1 , the students were unlikely to link their background knowledge with what they had just heard or group the heard information to restore them $(\mathrm{M}=2.14, \mathrm{SD}=.97)$. Likewise, most of the participants did not often use semantic mapping to learn word school or word order $(\mathrm{M}=2.46, \mathrm{SD}=1.14)$.

Table 1 . The memory strategies used

\begin{tabular}{|c|c|c|c|}
\hline \multirow{2}{*}{ Item } & Memory strategies & \multicolumn{2}{|c|}{$\mathbf{n = 3 6 8}$} \\
\cline { 2 - 4 } & M & SD \\
\hline 1 & $\begin{array}{c}\text { I link my background knowledge with what being heard or } \\
\text { group the information to restore. }\end{array}$ & $\mathbf{2 . 1 4}$ & $\mathbf{. 9 7}$ \\
\hline 2 & I use semantic mapping to learn the word school, word order. & $\mathbf{2 . 4 6}$ & $\mathbf{1 . 1 4}$ \\
\hline \multicolumn{2}{|c|}{ Average } & $\mathbf{2 . 3 0}$ & $\mathbf{1 . 0 6}$ \\
\hline
\end{tabular}

Qualitatively, twelve out of all the twenty participating interviewees $(60 \%)$ reported that they often used memory strategies for their listening. In particular, twelve students stated that they grouped information while listening to restore and it enabled them to comprehend and remember the listening text content more effectively.

However, the other eight students (40\%) pointed out their infrequent use of this strategy. These eleven-grade students' unwillingness to employ memory strategies in listening learning was explained by two main reasons. The first reason was that a few students did not know how to group the heard information. The second reason was acknowledged by a few participants that they found it difficult to activate their background knowledge associated with what they heard. For instance, SI10 shared, "memory strategies are really effective to keep, restore, remember and comprehend the heard information, but it is extremely challenging for me to utilize it."

Memory strategies significantly contribute to listeners' good listening comprehension ability as they help restore and retrieve the 
heard information (Kassem, 2015). However, the quantitative findings in this study showed that a great part of the participants did not often use memory strategies such as activating their background knowledge to store the auditory information, and semantic mapping to learn word order. Consistently, the qualitative results obtained from the interview highlighted that eight out of twenty student interviewees were unready to employ this memory strategy group. This result is completely contrary to Le's (2015) finding that memory strategy group was the most preferred compared to the other strategy groups.

Their ignorance may be explained by two causal factors that they did not know how to group information and found it arduous to activate their background knowledge with what they had listened. For this dilemma, most of the eleventh graders lacked a considerable amount of prior knowledge, which was found in the previous section. In reality, background knowledge can help the listeners survive when being exposed to difficult listening texts with the limited size of their lexicon.

\subsection{Cognitive strategies}

As Table 2 illustrated, many participants focused on grammar and structures to understand the listening texts better and repeated the information several times to facilitate their retention (item 3: $\mathrm{M}=3.72, \mathrm{SD}=1.25$ ).

Remarkably, most of the participants revealed that they tried to grasp the main ideas of the listening texts before focusing on other details or supporting ideas. This statement was clarified by the very high mean value (item 4 : $\mathrm{M}=4.19, \mathrm{SD}=.98)$.

Table 2. The cognitive strategies used

\begin{tabular}{|c|c|c|c|}
\hline \multirow{2}{*}{ Item } & Cognitive strategies & \multicolumn{2}{|c|}{$\mathbf{n = 3 6 8}$} \\
\cline { 3 - 4 } & M & SD \\
\hline 3 & $\begin{array}{c}\text { While listening, I focus on grammar, structures to understand the text better } \\
\text { and repeat several times to facilitate my retention. }\end{array}$ & $\mathbf{3 . 7 2}$ & $\mathbf{1 . 2 5}$ \\
\hline 4 & I try to grasp the main ideas before focusing on other details & $\mathbf{4 . 1 9}$ & $\mathbf{. 9 8}$ \\
\hline 5 & $\begin{array}{c}\text { I translate or make the contrast between English and Vietnamese words to } \\
\text { understand the language. }\end{array}$ & $\mathbf{4 . 1 0}$ & $\mathbf{1 . 0 7}$ \\
\hline 6 & I write down what I hear and summarize to understand texts better. & $\mathbf{3 . 6 8}$ & $\mathbf{1 . 2 4}$ \\
\hline & Average & $\mathbf{3 . 8 7}$ & $\mathbf{1 . 1 6}$ \\
\hline
\end{tabular}

Furthermore, some other strategies such as translating and contrasting (item 5) and notetaking (item 6) were also practically favored by the questionnaire respondents. First, almost all the eleventh graders understood the language in the listening texts by translating or making contrast between English or Vietnamese words or expressions $(\mathrm{M}=4.10, \mathrm{SD}=1.07)$. Also, many studied eleventh graders stated that they wrote down what they had heard and then summarized their notes to understand the listening texts better, shown by the high mean value (item 6: $\mathrm{M}=3.68, \mathrm{SD}=1.24$ ).
From the results gained from the interviews, all the students interviewed contended that they often favored using cognitive strategies in their listening learning. Most of the interviewees (75\%) focused on grammar and structures to understand the listening texts better, whereas two-thirds of them intentionally grasped the main idea before focusing on supporting ideas or details. While listening, eight interviewed participants (40\%) often wrote down what they heard and summarized their notes to understand listening texts better while exactly a half reported that they translated English to Vietnamese to 
understand what they heard better. In addition, repeating several times what they heard to increase their retention was practically preferred by three informants (15\%). In general, all the interviewees highly appreciated cognitive strategies which facilitated their comprehension of the listening texts, as SI7 said:

During my listening, I frequently guess the main idea first since it makes me to know what the listening is about. Furthermore, analyzing language structures in the listening texts and translating English into Vietnamese in my mind can facilitate my understanding. Actually, these strategies help me become more strategic in listening. (SI7)

Contrary to the memory strategies, a big proportion of the participants utilized cognitive strategies more frequently during their listening process. Theoretically, cognitive strategies are perceptions that listeners use to solve listening tasks, involving analyzing, synthesizing and transforming information or input they receive (Ellis, 1997). It is acknowledged that cognitive strategies play an integral part in improving learners' knowledge and their understanding of linguistic system (e.g. grammar, structures), helping students to develop the thinking skills that make them strategic and flexible (O’Malley et al., 1989). Indeed, if the learners focus on grammatical patterns in the listening texts and repeat the heard information several times, they are able to make connection between the newlyabsorbed information and their existing schema to retrieve appropriate data from long-term memory, and can easily predict what speakers are talking about.

Overall, it is a positive indication that the target high school students practically preferred cognitive strategy group to the other ones during their listening process. This result is quite similar to Bao's (2017) finding that cognitive strategies were more preferable than metacognitive and affective strategies. It is noteworthy that some previous studies (e.g. Kassem, 2015; Shahrokhi et al., 2015; Zhang, 2012) evidently showed the positive correlation between the frequency of the students' using cognitive strategies and listening comprehension. It should be noted that the more the listeners manipulate cognitive strategies, the more they are able to comprehend the listening texts.

\subsection{Compensation strategies}

Table 3 indicated that compensation strategies were unlikely preferred by many students with quite low mean score (item 7: $\mathrm{M}=2.81, \mathrm{SD}=1.28)$. Secondly, when encountering strange words in the listening texts, many eleven-grade students did not often use situational context (e.g. noise or speaker's tone of voice) to enhance their listening comprehension, which was statistically clarified by the low mean (item 8 : $\mathrm{M}=2.40, \mathrm{SD}=1.18$ ).

Table 3. The compensation strategies used

\begin{tabular}{|c|c|c|c|}
\hline \multirow{2}{*}{ Item } & Compensation strategies & \multicolumn{2}{|c|}{$\mathbf{n = 3 6 8}$} \\
\cline { 3 - 4 } & M & SD \\
\hline 7 & $\begin{array}{c}\text { To understand unfamiliar words I hear, I make guesses by using linguistic clue } \\
\text { such as word order. }\end{array}$ & $\mathbf{2 . 8 1}$ & $\mathbf{1 . 2 8}$ \\
\hline 8 & $\begin{array}{c}\text { To understand unfamiliar words I hear, I make guesses by using situational } \\
\text { context such as speaker's tone of voice. }\end{array}$ & $\mathbf{2 . 4 0}$ & $\mathbf{1 . 1 8}$ \\
\hline \multicolumn{2}{|c|}{\begin{tabular}{c} 
Average \\
\hline
\end{tabular}} & $\mathbf{2 . 6 4}$ & $\mathbf{1 . 2 1}$ \\
\hline
\end{tabular}


For the qualitative data, only three out of twenty interviewees $(15 \%)$ proclaimed that they often exploited compensation strategies while listening. Specifically, these students revealed that they frequently guessed the meaning of unfamiliar words they had heard by using linguistic clues (e.g. word order, word stress). For example, SI10 emphasized the necessity of this strategy that "I always confront many strange words in the listening texts. Thus, linguistic clues like word order or stress can help me much to treat this problem."

Contrariwise, the interview results showed that most of the interviewees $(85 \%)$ did not frequently employ any compensation strategies. The hesitance to use compensation strategies among these seventeen students was clarified by the primary reason that they found it tough to use compensation strategies.

According to Oxford(1990), compensation strategies facilitate learners to use the new language for either comprehension [listening] or production [speaking] despite limitations in knowledge. Specific to listening process, compensation strategies could help listeners make up for missing knowledge when they do not hear something clearly. Therefore, they could use clues to guess meaning of words or pieces of information.
However, as emerged from the questionnaire and interview findings, a great number of the participants did not make use of this strategy group and frankly revealed that they found it extremely tough to use compensation strategies and they actually scanted their confidence to this strategy group although Hardan (2013) pinpoints that compensation strategies are interaction techniques that are utilized by listeners to compensate for restrictions in their language when listeners cannot understand clearly what they heard due to the dearth of either linguistic input or topical knowledge.

\subsection{Metacognitive strategies}

As can be seen from Table 4, the overwhelming majority of the eleven-grade students often set up their clear goals such as listening for main ideas, listening for detail ideas or listening for identifying speakers' attitudes, which was supported by the very high mean (item 10: $\mathrm{M}=4.25, \mathrm{SD}=1.02$ ). Likewise, many high school students reported that they also often decided whether they focus on listening to the whole texts or just some parts (item 9: $\mathrm{M}=3.81, \mathrm{SD}=1.25$ ). However, self-monitoring listening strategy was not practically favored by the eleventh graders (item 11: $\mathrm{M}=2.32, \mathrm{SD}=1.11$ ).

Table 4. The metacognitive strategies used

\begin{tabular}{|c|c|c|c|}
\hline \multirow{2}{*}{ Item } & Metacognitive strategies & \multicolumn{2}{|c|}{$\mathbf{n = 3 6 8}$} \\
\cline { 3 - 4 } & $\mathbf{M}$ & SD \\
\hline 9 & I decide in advance whether I should be attentive to the whole task or details. & $\mathbf{3 . 8 1}$ & $\mathbf{1 . 2 5}$ \\
\hline 10 & $\begin{array}{c}\text { When listening, I had clear goals (listen for main ideas, listen for details, listen } \\
\text { for speakers' attitudes). }\end{array}$ & $\mathbf{4 . 2 5}$ & $\mathbf{1 . 0 2}$ \\
\hline 11 & $\begin{array}{c}\text { I self-monitor the listening process to avoid making mistakes I had before and } \\
\text { evaluate how well the task has been done. }\end{array}$ & $\mathbf{2 . 3 2}$ & $\mathbf{1 . 1 1}$ \\
\hline \multirow{2}{*}{\begin{tabular}{c} 
Average \\
\cline { 2 - 4 }
\end{tabular}} & $\mathbf{3 . 4 6}$ & $\mathbf{1 . 1 3}$ \\
\hline
\end{tabular}


The interview results showed that eighteen out of the twenty eleven-grade student interviewees (90\%) often employed metacognitive strategies for their listening process. Particularly, all these eighteen usually identified their clear goals before listening such as listening for gist, listening for details, or listening for speaker's attitudes. Moreover, fifteen out of these eighteen students $(75 \%)$ also reported that they frequently decided to focus on details or the whole listening text. However, in this group, only SI17 (5\%) revealed that she usually self-monitored the listening process to avoid making mistakes she had made before and evaluated how well the task had been done. Generally, almost all these interviewees highly applauded the good impacts of metacognitive strategies on their listening comprehension level. For example, SI6 highlighted that metacognitive strategies helped manage listening behaviors.

I consider that it is important for listeners to set up a clear purpose before listening since the fact that it will support me to manage my listening behaviors. To give a couple of examples, if we want to listen for details, we will try to hear as many small pieces of information as possible. On the contrary, if we listen for gist, we need to hear the whole text. (SI6)

In the same fashion, SI6 and SI8 stressed that these strategies could support the listener monitor listening progress. For this, SI8 said, "I frequently decide to focus on the whole listening text or just some details. [...] metacognitive strategies are good tools for listening directions."

In contrast, the interview results also indicated that two interviewees $(10 \%)$ did not frequently employ metacognitive strategies during their listening. By reason, the two students admitted that they did not know how to apply metacognitive strategies effectively; for example, SI10 stated:

To be honest, I almost never utilize metacognitive strategies. Actually, I do not know how to self-monitor during my listening and selfevaluate after my listening. I only try to hear what is spoken. To me, I am unable to monitor and evaluate my listening behaviors by myself. (SI10)

Theoretically, this strategy group is believed to play a vital role in facilitating the learners' language learning as it helps them "oversee, regulate, or direct the language learning process" (Vandergrift, 1999, p. 170). It means that metacognitive learning strategies help learners to know what to do when they come across difficulties. As Oxford (1990) asserts, metacognitive strategies are used to plan, monitor, and evaluate learning process, arrange the condition for someone to learn, set long and short term goals and check learners' comprehension during listening task.

In this study, setting up clear listening goal and deciding on what focus or ignore were the frequently practiced metacognitive strategies in many eleventh graders' listening learning. On the contrary, self-monitoring was still unfamiliar to most of the participating students. Obviously, in this study, almost all the participants only used the two first sets including centering and planning but the last one of self-evaluating. Unlike this finding, some previous studies such as Tavakoli et al. (2012), Coşkun (2013), Shahrokhi et al. (2015) discovered that a more proficient listener actively engaged in planning for the task and monitoring incoming input as well as evaluating output.

\subsection{Affective strategies}

Table 5 illustrated that a much greater part of the participants tried to breathe deeply to 
keep calm and comfortable before listening (item 12: $\mathrm{M}=4.28, \mathrm{SD}=.84$ ). Similarly, before listening, many students reminded themselves that they could finish listening tasks, which was elucidated by the high mean value (item 13, $\mathrm{M}=4.05, \mathrm{SD}=1.08)$. However, many students did not often share their feeling with their friends and encouraged themselves to concentrate on listening English even when they could not hear anything (item 14: $\mathrm{M}=$ 2.30, $\mathrm{SD}=1.06)$.

Table 5. The affective strategies used

\begin{tabular}{|c|c|c|c|}
\hline \multirow{2}{*}{ Item } & Affective strategies & \multicolumn{2}{|c|}{$\mathbf{n = 3 6 8}$} \\
\cline { 3 - 4 } & M & SD \\
\hline 12 & I try to relax or breathe deeply to keep calm before listening English. & $\mathbf{4 . 2 8}$ & $\mathbf{. 8 4}$ \\
\hline 13 & Before listening, I tell myself that I can finish the task. & $\mathbf{4 . 0 5}$ & $\mathbf{1 . 0 8}$ \\
\hline \multirow{2}{*}{14} & $\begin{array}{c}\text { I share my feeling with my friends and encourage myself to concentrate on } \\
\text { listening when I can't hear anything. }\end{array}$ & $\mathbf{2 . 3 0}$ & $\mathbf{1 . 0 6}$ \\
\hline \multicolumn{2}{|c|}{ Average } & $\mathbf{3 . 6 2}$ & $\mathbf{. 9 9}$ \\
\hline
\end{tabular}

Based on the interview results, all twenty student interviewees $(100 \%)$ reported that they often breathed deeply, self-relaxed and selfencouraged before listening. These students revealed that this affective strategy could help them reduce pressure and enhance their more concentration level for their coming listening process. For example, SI4 said that being comfortable and relaxed could make him concentrate more on listening texts.

To speak frankly, I claim that comfort plays an important role in speeding up listening comprehension ability. Therefore, I frequently breathe so deeply to make me relax before listening. It facilitates my concentration on listening. (SI4)

In a similar vein, SI13 emphasized that this affective strategy could reduce his anxiety and reinforce his concentration level before actual listening and "until I feel relaxed, I can hear something."

These strategies are directly associated with learners' positive emotional enhancement such as confidence and perseverance which helps learners to involve themselves actively in language learning, and lowering anxiety levels by laughing at their own mistakes as a typical example (Alhaysony, 2017). Hence, it is vital for students to remove their anxiety and energize their motivation in their listening learning.

Interestingly, the majority of respondents reported that they frequently breathed deeply to make themselves comfortable as well as reminded themselves to complete the listening tasks. Therefore, it is suggested that high school teachers should help generate positive feeling in class by increasing the amount of natural communication among their students.

\subsection{Social strategies}

It can be seen in Table 6 that a big number of the participants applauded the first social strategy in which they asked teachers or friends to clarify what they did not understand during their listening (item 15: $\mathrm{M}=4.17$, $\mathrm{SD}=1.01)$. Furthermore, more than a half of the eleventh graders reported that they frequently exchanged information to check comprehension and answered questions with friends after listening (item 16: $\mathrm{M}=3.46, \mathrm{SD}=$ $1.30)$. 
Table 6. The social strategies used

\begin{tabular}{|c|c|c|c|}
\hline \multirow{2}{*}{ Item } & Social strategies & \multicolumn{2}{|c|}{$\mathbf{n = 3 6 8}$} \\
\cline { 2 - 4 } & M & SD \\
\hline 15 & I ask the teacher or my friends to clarify what I am not clear. & $\mathbf{4 . 1 7}$ & $\mathbf{1 . 0 1}$ \\
\hline 16 & $\begin{array}{c}\text { After listening, I exchange the information with friends and cooperate to } \\
\text { check comprehension and answer questions. }\end{array}$ & $\mathbf{3 . 4 6}$ & $\mathbf{1 . 3 0}$ \\
\hline \multirow{2}{*}{\begin{tabular}{c} 
Average \\
\cline { 1 - 3 }
\end{tabular}} & $\mathbf{3 . 3 2}$ & $\mathbf{1 . 0 8}$ \\
\hline
\end{tabular}

Similarly, all the interviewed students $(100 \%)$ revealed that they often employed social strategies for their listening learning. In particular, all these interviewed participants usually exchanged information with their classmates. Besides, when being unclear about what they were listening, $60 \%$ of the informants usually asked their teachers or classmates for clarification. Overall, all the twenty interviewees highly agreed that these social strategies were one of the most effective strategies in listening learning. In fact, SI14 indicated that some high-level students could assist lower-level students.

Indeed, it is sure that some of my classmates are good enough to comprehend the listening texts and get the right answers. In other words, working together with them, I can enhance my comprehension ability on what is heard. (SI14)

Similarly, SI15 affirmed that comparing the listening answers helped accomplish listening tasks better later.

Social strategies assist me so much to comprehend what I have heard. In my case, I try to listen and then I usually have my answers compared with my friends'. As a result, I can know where I was wrong, and then I listen better. (SI15)

Social strategies include two sets of asking for question and cooperating with one another (Oxford, 1990). Particularly, asking for help from teachers or friends could enable listeners to clarify what they were not clear, and working with peers helped listeners check their comprehension and solve questions because it was believed that some high-level students could support their lower-level classmates. This strategy was considered one of the most direct and effective ways to accomplish the listening tasks and enhance listening comprehension at any rate since according to Oxford (1990), these strategies can help listeners work together and understand the target language. It is implied that the eleventh graders in this study cannot improve their existing listening ability considerably unless they work more frequently with their classmates.

\section{Conclusions and recommendations}

In general, almost all participants used the listening strategies to facilitate their listening comprehension, and there was a considerable difference in the frequency of using the listening strategies. Specifically, a significant proportion of the participants utilized cognitive strategies (e.g. focusing on grammar and structures of the listening texts, repeating the heard information, getting the main ideas before concentrating on supporting ideas, translating and taking notes for summary) more frequently while listening. The students considered that cognitive strategies played an integral part in improving learners' knowledge and their understanding of linguistic system, helping students to develop the thinking skills that make them strategic and flexible. 
Likewise, metacognitive strategies were favorably used by many students. Evidently, they frequently set up clear listening goals and decided on what to focus or ignore. By reason, these strategies actually supported them to manage the listening process, and direct their listening behaviors.

A large number of the participants also favorably utilized social strategies in which they asked teachers or friends to clarify what they did not understand during their listening. And, after listening, they exchanged information with friends and cooperated to check comprehension and answered questions. These social strategies were in favor as some high-level students could support their lowerlevel classmates, while comparing answers among listeners could help them do the listening tasks better.

Interestingly, most of the respondents highly appreciated the effects of affective strategies by frequently breathing deeply to keep calm as well as reminding themselves to complete the listening tasks. This strong favor derived from the fact that these strategies could help them reduce pressure and enhance their concentration and confidence level for their coming listening process.

Contrary to the aforementioned strategies, a great part of the participants did not often use memory strategies such as activating their background knowledge to store the just-heard information, and semantic mapping to learn word order. This low preference was stemmed from the two causal factors that they did not know how to group information and found it difficult to activate knowledge related to what they had listened.

In a similar vein, a great part of the respondents did not take advantage of compensation strategies such as guessing from linguistic or contextual clues to understand unfamiliar words during their listening. Admittedly, they found it extremely tough to use such compensation strategies.

To enhance the high school students' listening comprehension with the use of listening learning strategies, some suggestions for students, teachers and future research are offered as follows.

\subsection{For students}

Firstly, the eleventh graders faced phonological and lexical difficulties in listening. Positively, many of them favored cognitive strategies such as focusing on grammar and vocabulary of the listening texts. This is an effective listening strategy group which can help them control the input or use a certain skill to complete a particular task, and enable them to understand and produce new language in many different ways. In fact, however, there always exist too many unfamiliar words in a listening text. It is suggested that the listeners should exploit memory strategies including grouping the heard information in their mind to store as well as activating their background knowledge. As a result, these listeners can grasp the meaning of the listening texts better. That is the reason why the eleventh graders in this study need to employ memory strategies more frequently.

Secondly, almost all the high school students confronted semantic problems in their listening. The causal factors for this inconvenience were that the students encountered unfamiliar topics and they also lacked their background knowledge. In contrast, they did not prefer using compensation strategies such as guessing from linguistic and contextual clues. It is recommended that compensation strategies need to be utilized to rescue the students from knowledge limitations in listening skill. This could be supported by what Oxford (1990) 
claims, "[f]or beginning and intermediate language learners, these strategies may be among the most important" (p. 90). In short, a successful listener needs to use both bottomup processing (like textual cues) and topdown processing (like prior knowledge and experience). In other words, good listening comprehension ability also requires students to actively equip themselves with a wide range of lexical resources and topic-based knowledge.

Thirdly, both the questionnaire and interview results showed that most of the students had severe problems with their recognition of the overall structure of listening texts including main ideas, details, etc. Thus, the high school students should use metacognitive learning strategies for planning before listening such as listening for gist, listening for details, etc. and for monitoring their listening behaviors such as note-taking and summarizing, linguistically concentrating (cognitive strategies), information grouping (memory strategies) or contextual-based guessing (compensation strategies), and so on. Consequently, the listeners can get the overall picture of listening texts from specific information to general idea. It is suggested that both planning strategy and reflective strategy should be employed to assist students to create good listening habits and to be strategic in their listening learning.

Fourthly, a striking finding emerged from the study is that the majority of these high school students were in favor of social and affective strategies in their listening learning. For instance, they used to learn listening skill by interacting with their classmates and answering the teacher's questions for clarity or trying to lower their anxiety. It is highly recommended that the high school students should use social and affective strategies to collaborate with others, to verify understanding or to lower anxiety, which are ranked as the most effective strategies in terms of enhancing listening comprehension among students.

Succinctly stated, almost all the student participants faced several listening challenges, which negatively affected their listening comprehension. In order to improve their listening comprehension, apart from equipping with both language and background knowledge for listening, it is necessary that high school students should raise their awareness of different listening strategies and employ them sufficiently.

\subsection{For teachers}

In an attempt to improve EFL students' listening outcomes, teachers' roles should be taken into account. Therefore, the present study gives some pedagogical implications for EFL teachers in general and Duong Van Duong high school teachers in particular.

First of all, high school teachers have to make sure that students fully understand listening learning strategy groups, so they can apply these strategies in their listening appropriately and flexibly. To this end, teachers should provide their students with various listening strategy groups consciously according to each stage of listening (prelistening, while-listening, and post-listening). More specifically, based on Oxford's (1990) strategy classification system, the authors would like to make the following suggestions. Direct strategies which consist of (1) cognitive strategies (getting ideas quickly, note-taking, summarizing, translating, recognizing and using patterns, repeating, transferring, and analyzing contrastively), (2) compensation strategies (using other clues and using linguistics) and (3) memory strategies (grouping and associating/elaborating ideas) should be predominantly applied for while- 
listening stage. Meanwhile, indirect strategies including (1) metacognitive strategies (setting goals and objectives, self-monitoring, and self-evaluating), (2) affective strategies (using progressive relaxation, listening to your body, and discussing your feelings with someone else), and (3) social strategies (asking for clarification and cooperating with peers) are likely to be appropriate for pre-listening and post-listening stages.

Second, teachers need to modify listening tasks in the textbooks so that high school students vary their use of listening learning strategies. Especially, at the end of the listening sections, high school teachers need to reinforce their students' understanding and experience of the listening strategies during these listening tasks. As a result, students can self-regulate and moderate their listening performance in the future. In this case, it is suggested that teachers should use metacognitive strategies to promote their students' autonomous learning and social ones to cross-check students' listening comprehension.

Third, high school teachers should encourage their students to practice listening comprehension at home and participate in group work or pair work activities in class to reduce students' psychological issues. To deal with this issue, affective strategies are highly recommended.

Last but not least, to support students' English listening comprehension, listening subskills involving summarizing, notetaking, listening for gist, listening for specific information, inferring, listening extensively, deducing meaning from context, guessing, dealing with connected speech, etc. should be taught to students prior to listening texts (Spratt \& Williams, 2011). To this end, metacognitive, memory and compensation strategies are necessarily included.

\subsection{For further research}

It is undeniable that the findings of this study offer theoretical and practical contributions to language teaching and research. Due to time limit, nevertheless, limited research instruments (e.g. questionnaire and interview) were employed, and only the frequency of used listening learning strategies was investigated. Hence, it is recommended that further research should extend the time for exploiting more research instruments like test or classroom observation to assure the triangulation of the data collection instruments. Furthermore, the relationship between students' academic achievement and listening learning strategies should be taken into account.

\section{References}

Alhaysony, M. (2017). Language learning strategies use by Saudi EFL students: The effect of duration of English language study and gender. Theory and Practice in Language Studies, 7(1), 18-28.

Berne, J.E. (2004). Listening comprehension strategies: A review of the literature. Foreign Language Annals, 37(4), 521-531. doi: 10.1111/j.1944-9720.2004.tb 02419.x.

Bao, X. (2017). A Study on Listening Strategies Instructed by Teachers and Strategies Used by Students. International Journal of English Linguistics, 7(2), 186-195.

Brown, S. (2006). Teaching Listening. Cambridge University Press.

Chen, A-H. (2013). EFL Listeners' Strategy Development and Listening Problems: A ProcessBased Study. The Journal of Asia TEFL, 10(3), 81101

Coşkun, A. (2010). The effect of metacognitive strategy training on the listening performance of beginner students. Novitas-ROYAL (Research on Youth and language), 4(1), 35-50.

Do Thi Minh Chau (2007). Teaching listening comprehension at Food Industry College of Ho Chi Minh City [Unpublished Master's thesis]. Vietnam: University of Social Sciences \& Humanities.

Ellis, R. (1997). Second Language Acquisition. Oxford: Oxford University Press.

Hardan, A. A. (2013). Language Learning 
Strategies: A General Overview. Procedia-Social and Behavioral Sciences, 106, 1712-1726.

Harmer, J. (2007). The Practice of English Language Teaching. Harlow: Longman

Kassem, H. M. (2015). The Relationship between Listening Strategies Used by Egyptian EFL College Sophomores and Their Listening Comprehension and Self-Efficacy. English Language Teaching, 8(2), 153-169.

Le Huynh Thanh Huy (2015). An Investigation into Listening Strategies of EFL Students within the High School Setting. Asian Journal of Educational Research, 3(4), 21-34.

Manzouri, H., Shahraki, A. \& Fatemi, S. (2016). Effect of Listening Proficiency on Types of Listening Strategies Used by Iranian EFL Learners. International Journal of English Language and Translation Studies, 30-41.

Nguyen Thi Boi Hoang (2013). English learning strategies of Vietnamese tertiary students (Unpublished doctoral thesis). University of Tasmania, Australia.

Nguyen Hoang Tuan \& Tran Ngoc Mai (2015). Factors affecting students' speaking performance at Le Thanh Hien high school. Asian Journal of Educational Research, 3(2), 8-23.

O'Malley, J. M., \& Chamot, A. U. (1990). Learning strategies in second language acquisition. Cambridge, England: Cambridge University Press.

O'Malley, J., Chamot, A., \& Kupper, L. (1989). Listening comprehension strategies in second language acquisition. Applied Linguistics, 10, 418437.
Oxford, R. (1990). Language learning strategies: What every teacher should know. Boston, MA: Heinle \& Heinle.

Shahrokhi, M., Malekian, P., \& Sayedi, S. B. (2015). Listening Comprehension Ability and the Use of Listening Strategies by Iranian Pre-intermediate EFL Learners. Journal of Applied Linguistics and Language Research, 2(5), 231-241.

Spratt, M., Pulverness, A., \& Williams, M. (2011). The TKT Course Modules 1, 2 and 3. Cambridge: Cambridge University Press.

Tavakoli, M., Shahraki, S., \& Rezazadeh, M. (2012). The relationship between metacognitive awareness and EFL listening performance: focusing on IELTS higher and lower scorers. The Journal of Language Teaching and Learning, 2, 24-37.

Ur, P. (1984). Teaching Listening Comprehension. Cambridge: Cambridge University Press.

Vandergrift, L. (1999). Facilitating second language listening comprehension: Acquiring successful strategies. ELT Journal, 53(3), 168-176.

Vandergrift, L. (2007). Recent developments in second and foreign language listening comprehension research. Language Teaching, 40(3), 191-210.

Wenden, A., \& Rubin, J. (1987). Learner Strategies in Language Learning. Englewood Cliffs, NJ: Prentice Hall.

Wilson, J. J. (2008). How to Teach Listening. Malaysia: Pearson Education Limited.

Zhang, Y. (2012). The Impact of Listening Strategy on Listening Comprehension. Theory and Practice in Language Studies, 2(3), 625-629. 


\title{
TİM HIỂU VIỆC SƯ DƯNG CHIẾN LƯỢC HỌC NGHE TIẾNG ANH CỦA HỌC SINH LỚP 11 TẠI TRƯƠ'NG THPT DƯƠNG VĂN DƯO'NG
}

\author{
Dương Mỹ Thẩm ${ }^{1}$, Trần Thị Hoàng Trang ${ }^{2}$, Trần Quốc Thao ${ }^{3}$ \\ 1. Trường Đại học Nông Lâm Tp. Hồ Chí Minh, \\ Linh Trung, Thủ Đức, Tp. Hồ Chí Minh, Việt Nam \\ 2. Trương THPT Duơng Văn Dương, \\ Số 39 đường số 6, Phú Xuân, Nhà Bè, Tp. Hồ Chí Minh, Việt Nam \\ 3. Truờng Đại học Công nghệ Tp. Hồ Chi Minh, \\ 475A Điện Biên Phủ, Phường 25, Bình Thạn, Tp. Hồ Chí Minh, Việt Nam
}

Tóm tắt: Nghe hiểu là một trong bốn kỹ năng quan trọng nhất khi học bất kì ngôn ngữ nào. Nó đòi hỏi người học thông thạo cả kiến thức cơ bản và kiến thức ngôn ngữ học. Nhiều nghiên cứu đã chỉ ra rằng các chiến lược nghe có thể giúp người học ngôn ngữ xử lý được các thông tin khi giao tiếp. Vì thế, nghiên cứu này nhằm tìm hiểu xem học sinh lớp 11 tại Trường THPT Dương Văn Dương có sử dụng các chiến lược nghe trong quá trình học nghe tiếng Anh hay không và sau đó tìm hiểu sâu hơn về mức độ sử dụng các chiến lược nghe. Nghiên cứu sử dụng cả dữ liệu định lượng và định tính. Cụ thể, có 425 học sinh trả lời bảng câu hỏi và sau đó, 20 trong số họ được đề nghị tham gia phỏng vấn bán cấu trúc. Kết quả nghiên cứu cho thấy các đối tượng nghiên cứu sử dụng các nhóm chiến lược nghe tiếng Anh với mức độ khác nhau và được chia thành 03 nhóm chính: nhóm sử dụng nhiều (gồm chiến lược nhận thức và cảm xúc), nhóm sử dụng vừa phải (gồm chiến lược siêu nhận thức và xã hội) và nhóm sử dụng ít (gồm chiến lược bù đắp và trí nhớ).

Từ khóa: nghe hiểu tiếng Anh, học sinh lớp 11, chiến lược nghe, ngữ cảnh Việt Nam

\section{APPENDIX A}

\section{STUDENT QUESTIONNAIRE}

This questionnaire belongs to a study named "Eleventh Graders' Actual Use of Listening Learning Strategies at Duong Van Duong High School". We highly appreciate it if you could spend your time answering following questions. Your responses will greatly contribute to the success of this paper. Your replies will be only used for survey purposes. Thank you very much for your cooperation.

\section{Personal information}

Please provide your own information by putting a cross $(X)$ in the box or write down your information.

1. Gender: $\square$ Male $\square$ Female

2. How long have you learnt English? - About years. 


\section{Actual use of listening learning strategies}

1. Did you employ listening learning strategies in the English class?
$\square$ Yes
$\square$ No
$\square$ I don't know

(If yes, please continue to answer the rest of the questionnaire)

2. How often do you employ listening learning strategies?

Please put a cross $(X)$ and rate yourself based on the given statements using the following scale:

\begin{tabular}{|c|c|c|c|c|c|c|}
\hline \multicolumn{7}{|c|}{$1=$ never, $2=$ rarely, $3=$ occasionally, $4=$ frequently, $5=$ always } \\
\hline \multicolumn{7}{|c|}{ 1. MEMORY STRATEGIES } \\
\hline 1 & $\begin{array}{l}\text { I link my background knowledge with what being heard or group the } \\
\text { information to restore them. }\end{array}$ & 1 & 2 & 3 & 4 & 5 \\
\hline 2 & I use semantic mapping to learn the word school and word order. & 1 & 2 & 3 & 4 & 5 \\
\hline \multicolumn{7}{|c|}{ 2. COGNITIVE STRATEGIES } \\
\hline 3 & $\begin{array}{l}\text { While listening, I focus on grammar and structures to understand } \\
\text { the text better and repeat information several times to facilitate my } \\
\text { retention. }\end{array}$ & 1 & 2 & 3 & 4 & 5 \\
\hline 4 & I try to grasp the main ideas before focusing on other small details. & 1 & 2 & 3 & 4 & 5 \\
\hline 5 & $\begin{array}{l}\text { I translate, transfer or make the contrast between English and } \\
\text { Vietnamese words or expressions to understand the target language. }\end{array}$ & 1 & 2 & 3 & 4 & 5 \\
\hline 6 & $\begin{array}{l}\text { I write down what I hear and summarize my notes to understand } \\
\text { listening texts better. }\end{array}$ & 1 & 2 & 3 & 4 & 5 \\
\hline \multicolumn{7}{|c|}{ 3. COMPENSATION STRATEGIES } \\
\hline 7 & $\begin{array}{l}\text { To understand unfamiliar words I hear, I make guesses by using } \\
\text { linguistic clue such as word order and word stress. }\end{array}$ & 1 & 2 & 3 & 4 & 5 \\
\hline 8 & $\begin{array}{l}\text { To understand unfamiliar words I hear, I make guesses by using } \\
\text { situational context such as noise and speaker's tone of voice. }\end{array}$ & 1 & 2 & 3 & 4 & 5 \\
\hline \multicolumn{7}{|c|}{ 4. METACOGNITIVE STRATEGIES } \\
\hline 9 & $\begin{array}{l}\text { I decide in advance whether I should be attentive to the whole task or } \\
\text { particular details. }\end{array}$ & 1 & 2 & 3 & 4 & 5 \\
\hline 10 & $\begin{array}{l}\text { When listening, I had clear goals (listen for main ideas, listen for } \\
\text { detail ideas or listen for identifying speakers' attitudes) }\end{array}$ & 1 & 2 & 3 & 4 & 5 \\
\hline 11 & $\begin{array}{l}\text { I self - monitor the listening process to avoid making mistakes I had } \\
\text { before and evaluate how well the task has been done. }\end{array}$ & 1 & 2 & 3 & 4 & 5 \\
\hline \multicolumn{7}{|c|}{ 5. AFFECTIVE STRATEGIES } \\
\hline 12 & I try to relax or breathe deeply to keep calm before listening English. & 1 & 2 & 3 & 4 & 5 \\
\hline 13 & Before listening, I tell myself that I can finish the task. & 1 & 2 & 3 & 4 & 5 \\
\hline 14 & $\begin{array}{l}\text { I share my feeling with my friends and encourage myself to } \\
\text { concentrate on listening English even when I can't hear anything. }\end{array}$ & 1 & 2 & 3 & 4 & 5 \\
\hline \multicolumn{7}{|c|}{ 6. SOCIAL STRATEGIES } \\
\hline 15 & I ask the teacher or my friends to clarify what I am not clear. & 1 & 2 & 3 & 4 & 5 \\
\hline 16 & $\begin{array}{l}\text { After listening, I exchange the information with friends and cooperate } \\
\text { to check comprehension and answer questions. }\end{array}$ & 1 & 2 & 3 & 4 & 5 \\
\hline
\end{tabular}




\section{APPENDIX B SEMI-STRUCTURED INTERVIEW}

\section{The frequency of employing listening learning strategies}

1. How often do you use Memory Strategies for your listening learning? If yes, how are these strategies useful for your learning? If no, why aren't they employed to improve your listening skill?

2. Do you frequently use Cognitive Strategies for your listening learning process? Which of the following techniques are often utilized for your listening?

3. Do you often exploit Compensation Strategy (guessing intelligently based on linguistics and other clues) to facilitate your listening learning? If yes, can you give some examples how is the strategy helpful for you? If not, what are your obstacles?

4. Have you employed Metacognitive Strategies with high frequency? If yes, specify your situations? If no, why?

5. How frequently do you use relaxation, deep breathing, or mediation to reduce your pressure before or while listening? If yes, what benefits do you get from these techniques? If no, why do you pay no or little attention to them?

6. Do you often ask for clarification or Cooperate with peers to accomplish listening tasks? In your opinion, are these techniques useful for your learning? Why or why not? 